\title{
EFFECT OF SULPHIDE INCLUSIONS ON THE PITTING-CORROSION BEHAVIOUR OF HIGH-Mn STEELS IN CHLORIDE AND ALKALINE SOLUTIONS
}

\author{
VPLIV SULFIDNIH VKLJUČKOV NA JAMIČASTO KOROZIJO \\ JEKEL Z VISOKO VSEBNOSTJO Mn V RAZTOPINAH KLORIDOV \\ IN ALKALIJ
}

\author{
Adam Grajcar, Aleksandra Plachcińska \\ Silesian University of Technology, Institute of Engineering Materials and Biomaterials, Konarskiego Street 18a, 44-100 Gliwice, Poland \\ adam.grajcar@polsl.pl
}

Prejem rokopisa - received: 2015-07-01; sprejem za objavo - accepted for publication: 2015-09-02

doi: $10.17222 /$ mit.2015.169

\begin{abstract}
The corrosion behaviour of the 27Mn-4Si-2Al- and 26Mn-3Si-3Al-type austenitic steels were evaluated in chloride $3.5 \% \mathrm{NaCl}$ and alkaline $0.1-\mathrm{M} \mathrm{NaOH}$ environments using potentiodynamic polarization tests. The type of non-metallic inclusions and their pitting-corrosion behaviour were investigated. In the chloride solution, both the steels exhibited a lower corrosion resistance in comparison to the alkaline solution. The high-Mn steels showed evidence of pitting and uniform corrosion, both in the chloride and alkaline solutions. SEM micrographs revealed that the corrosion pits are characterized by various shapes and an irregular distribution at the metallic matrix. Corrosion damage is more numerous in the chloride solution than in the alkaline solution. EDS analyses revealed that the corrosion pits nucleated on MnS inclusions or complex oxysulphides. The chemical composition of the steels (change in the $\mathrm{Al}$ and $\mathrm{Si}$ contents) does not affect the privileged areas of pit nucleation, whereas it influences the electrochemical behaviour of the steels in the chloride solution.

Keywords: high-Mn steel, austenitic steel, non-metallic inclusion, corrosion resistance, pitting corrosion, potentiodynamic polarization test
\end{abstract}

Korozijsko obnašanje avstenitnih jekel $27 \mathrm{Mn}-4 \mathrm{Si}-2 \mathrm{Al}$ in $26 \mathrm{Mn}-3 \mathrm{Si}-3 \mathrm{Al}$ je bilo ocenjeno v raztopini $3,5 \% \mathrm{NaCl}$ in v alkalni raztopini $0,1 \mathrm{M} \mathrm{NaOH}$, s pomočjo potenciodinamičnih polarizacijskih preizkusov. Preiskovana je bila vrsta nekovinskih vključkov in njihovo ponašanje pri jamičasti koroziji. V raztopini kloridov sta obe jekli, v primerjavi z alkalno raztopino, pokazali manjšo korozijsko obstojnost. Jekla z visoko vsebnostjo Mn so pokazala jamičasto in splošno korozijo v obeh raztopinah, tako v kloridni kot $\mathrm{v}$ alkalični. SEM-posnetki so pokazali korozijske jamice različnih oblik in njihovo neenakomerno razporeditev po kovinski osnovi. Korozijske poškodbe so bolj številne v kloridni raztopini kot pa v alkalni raztopini. EDS-analize so pokazale, da korozijske jamice nastajajo na vključkih MnS ali na kompleksnih oksisulfidih. Kemijska sestava jekel (spremembe $\mathrm{V}$ vsebnosti $\mathrm{Al}$ in $\mathrm{Si}$ ) ni vplivala na prednostna mesta nukleacije jamic, medtem ko je vplivala na elektrokemijsko ponašanje jekel $v$ raztopini kloridov.

Ključne besede: jekla z veliko vsebnostjo Mn, avstenitno jeklo, nekovinski vključki, odpornost na korozijo, jamičasta korozija, potenciodinamični polarizacijski preizkus

\section{INTRODUCTION}

Pitting corrosion is a type of localized corrosion. It occurs mainly in the passive state of metals, in environments containing aggressive ions, i.e., chloride anions. The pits are often invisible during the formation stage, but their progressive local damage can lead to an element perforation. ${ }^{1}$ It is well known that various factors - the chemical composition, microstructure, heat treatment and plastic deformation - affect the pitting potential. ${ }^{2-4}$

There are many reports that confirm the negative impact of non-metallic inclusions on the corrosion resistance of steel. ${ }^{5-7}$ High-manganese austenitic steels have different types of inclusions, which form during melting and casting. These steels contain $\mathrm{Mn}$, which combines with sulphur, and $\mathrm{Si}$ and $\mathrm{Al}$ additions with a high chemical affinity for oxygen (Al also to nitrogen). ${ }^{8-10}$ Therefore, the presence of various sulphide and oxide inclusions in these steels can be expected. ${ }^{11,12}$ I. J. Park et al. ${ }^{7}$ observed MnS, $\mathrm{AlN}, \mathrm{Al}_{2} \mathrm{O}_{3}, \mathrm{MnAl}_{2} \mathrm{O}_{4}$ and other complex inclusions in Mn-Al steels. Č. Donik et al. ${ }^{5}$ and A. Pardo et al. ${ }^{6}$ reported that the $\mathrm{Mn}$ additions to stainless steels have a detrimental effect on the pitting-corrosion resistance in a $\mathrm{NaCl}$ medium. Manganese favours the formation of $\mathrm{MnS}$ inclusions, which are vulnerable to the initiation of corrosion pits. Moreover, its presence drastically increases the corrosion current density of steel and displaces the $E_{\text {corr }}$ values towards less noble potentials. K. J. Park and H. S. Kwon ${ }^{13}$ found that the size of the $\mathrm{MnS}$ inclusions increased with an increase in the $\mathrm{Mn}$ concentration in $\mathrm{Fe}-18 \mathrm{Cr}-6 \mathrm{Mn}$ and $\mathrm{Fe}-18 \mathrm{Cr}-12 \mathrm{Mn}$ steels. The shape, composition and distribution of inclusions have significant effects on the corrosion resistance too.

The high-manganese alloys belong to a new, advanced group of steels that combine successively high strength and high plasticity due to the austenitic microstructure. Because of the homogeneous ductile micro- 
structure they can be used for numerous elements of the energy-absorbing structures of cars. ${ }^{14,15}$ These steels are used as a cheaper substitute for austenitic stainless steels. Manganese (austenite stabilizer) and aluminium can replace expensive nickel and chromium additions. The potential applications also include construction materials to transport different liquid gases with various $\mathrm{pH}$ values. However, their real application also depends on the corrosion behaviour. Therefore, the effect of non-metallic inclusions on the corrosion properties of the $27 \mathrm{Mn}-4 \mathrm{Si}-$ $2 \mathrm{Al}$ and $26 \mathrm{Mn}-3 \mathrm{Si}-3 \mathrm{Al}$ steels in two environments, i.e., $3.5 \% \mathrm{NaCl}$ (neutral) and 0.1-M NaOH (alkaline), have been investigated in this study using electrochemical polarization tests.

\section{EXPERIMENTAL PROCEDURE}

The investigated materials were high-Mn austenitic steels with the chemical composition shown in Table $\mathbf{1 .}$ Both steels were treated using the same conditions. The steel ingots were prepared by vacuum melting, then they were hot-forged and roughly rolled to a thickness of $4.5 \mathrm{~mm}$. The next step was their thermomechanical processing, consisting of the hot rolling of flat samples in three passes (relative reductions: $25 \%, 25 \%$ and $20 \%$ ) to a final sheet thickness of approximately $2 \mathrm{~mm}$, obtained at $850{ }^{\circ} \mathrm{C}$. Subsequently, the samples were rapidly cooled in water to room temperature.

The flat samples of the $27 \mathrm{Mn}-4 \mathrm{Si}-2 \mathrm{Al}$ and $26 \mathrm{Mn}-$ $3 \mathrm{Si}-3 \mathrm{Al}$ steels with a $0.38 \mathrm{~cm}^{2}$ exposed surface area were prepared for the electrochemical tests in $3.5 \% \mathrm{NaCl}$ (neutral) and $0.1-\mathrm{M} \mathrm{NaOH}$ (alkaline) solutions. The samples were mechanically ground with $\mathrm{SiC}$ paper up to 1200 grit. Prior to the experiments, all the samples were washed in distilled water and rinsed in acetone. The solutions were prepared using deionised water. The electrochemical cell comprised three electrodes. A stainless steel and a silver/silver chloride $(\mathrm{Ag} / \mathrm{AgCl})$ electrode (SSE) were used as the counter and the reference electrodes, respectively. The electrochemical measure- ments were performed using an Atlas 0531 Electrochemical Unit potentiostat/galvanostat driven by AtlasCorr05 software. The potentiodynamic polarisation measurements were conducted at a scan rate of $1 \mathrm{mV} / \mathrm{s}$. The potentiodynamic scan data were collected to determine the electrochemical parameters: corrosion potential $E_{\text {corr }}$ and corrosion current density $I_{\text {corr }}$.

The samples after the corrosion tests were polished using $\mathrm{Al}_{2} \mathrm{O}_{3}$ with a granularity of $0.1 \mu \mathrm{m}$ for the scanning electron microscopy (SEM). To reveal the corrosion pits the cover formed on the pit surface has to be removed. Thus, the samples' surfaces were polished to obtain a uniform surface with pit-initiation sites. The corrosion damage was examined based on SEM observations and EDS techniques. Additionally, the depth of the corrosion damage on the cross-sectioned specimens was evaluated using a light microscope.

\section{RESULTS AND DISCUSSION}

Typical microstructures of the $27 \mathrm{Mn}-4 \mathrm{Si}-2 \mathrm{Al}$ and 26Mn-3Si-3Al steel specimens are shown in Figures 1a and $\mathbf{1 b}$, respectively. Both micrographs exhibit relatively coarse austenite grains elongated according to the direction of hot rolling. The mean grain size is approximately $80 \mu \mathrm{m}$. The microstructures reveal the presence of annealing twins, deformation effects and elongated sulphide inclusions.

Potentiodynamic curves of the $27 \mathrm{Mn}-4 \mathrm{Si}-2 \mathrm{Al}$ and 26Mn-3Si-3Al steels registered in $3.5 \% \mathrm{NaCl}$ (neutral $\mathrm{pH} 7$ ) and $0.1-\mathrm{M} \mathrm{NaOH}$ (alkaline - $\mathrm{pH} 14$ ) solutions are illustrated in Figures 2 and 3. The average calculated values of the corrosion potential $E_{\text {corr }}$ and the corrosion current density $I_{\text {corr }}$ determined by the Tafel extrapolation are shown in Table 2. Both steels show lower corrosion resistance in the $3.5 \% \mathrm{NaCl}$ solution than in $0.1-\mathrm{M}$ $\mathrm{NaOH}$ solution. The corrosion current density registered in the chloride solution was higher in comparison to the alkaline solution (Table 2). The obtained data are supported by the similar results of other authors ${ }^{16,17}$, who reported that the high-Mn austenitic steels show a lower

Table 1: Chemical composition of investigated steels in mass fractions $(w / \%)$

Tabela 1: Kemijska sestava preiskovanih jekel v masnih deležih (w/\%)

\begin{tabular}{|c|c|c|c|c|c|c|c|c|c|c|}
\hline Grade & $\mathrm{Mn}$ & $\mathrm{Si}$ & $\mathrm{Al}$ & $\mathrm{S}$ & $\mathrm{P}$ & $\mathrm{Nb}$ & $\mathrm{Ti}$ & $\mathrm{N}$ & $\mathrm{O}$ & $\mathrm{Fe}$ \\
\hline 27Mn-4Si-2Al & 27.5 & 4.18 & 1.69 & 0.017 & 0.004 & 0.033 & 0.010 & 0.0028 & 0.0006 & bal. \\
\hline 26Mn-3Si-3Al & 26.0 & 3.08 & 2.87 & 0.013 & 0.002 & 0.034 & 0.010 & 0.0028 & 0.0006 & bal. \\
\hline
\end{tabular}

Table 2: Average values of the electrochemical polarization data for the $27 \mathrm{Mn}-4 \mathrm{Si}-2 \mathrm{Al}$ and $26 \mathrm{Mn}-3 \mathrm{Si}-3 \mathrm{Al}$ steels obtained in the $3.5 \% \mathrm{NaCl}$ and $0.1-\mathrm{M} \mathrm{NaOH}$ solutions

Tabela 2: Srednje vrednosti podatkov elektrokemijske polarizacije $27 \mathrm{Mn}-4 \mathrm{Si}-2 \mathrm{Al}$ in $26 \mathrm{Mn}-3 \mathrm{Si}-3 \mathrm{Al}$ jekel, dobljene v raztopinah $3,5 \% \mathrm{NaCl}$ in $0,1 \mathrm{M} \mathrm{NaOH}$

\begin{tabular}{|c|c|c|c|c|c|}
\hline \multirow{2}{*}{ Grade } & \multirow{2}{*}{ Statistics } & \multicolumn{2}{|c|}{$3.5 \% \mathrm{NaCl}$} & \multicolumn{2}{c|}{$0.1 \mathrm{MaOH}$} \\
\cline { 2 - 5 } & & $E_{\mathrm{corr}} /(\mathrm{mV})$ & $I_{\text {corr }} /\left(\mathrm{mA} / \mathrm{cm}^{2}\right)$ & $E_{\mathrm{corr}} /(\mathrm{mV})$ \\
\hline \multirow{2}{*}{$27 \mathrm{Mn}-4 \mathrm{Si}-2 \mathrm{Al}$} & -788 & 0.090 & -392 \\
& average value & 6.5 & 0.007 & 3.2 \\
\cline { 2 - 6 } & standard deviation & -785 & 0.009 & -395 \\
\hline \multirow{2}{*}{$26 \mathrm{Mn}-3 \mathrm{Si}-3 \mathrm{Al}$} & average value & 11.2 & 0.005 & 0.002 \\
\cline { 2 - 6 } & standard deviation & & 0.005 & 0.003 \\
\hline
\end{tabular}



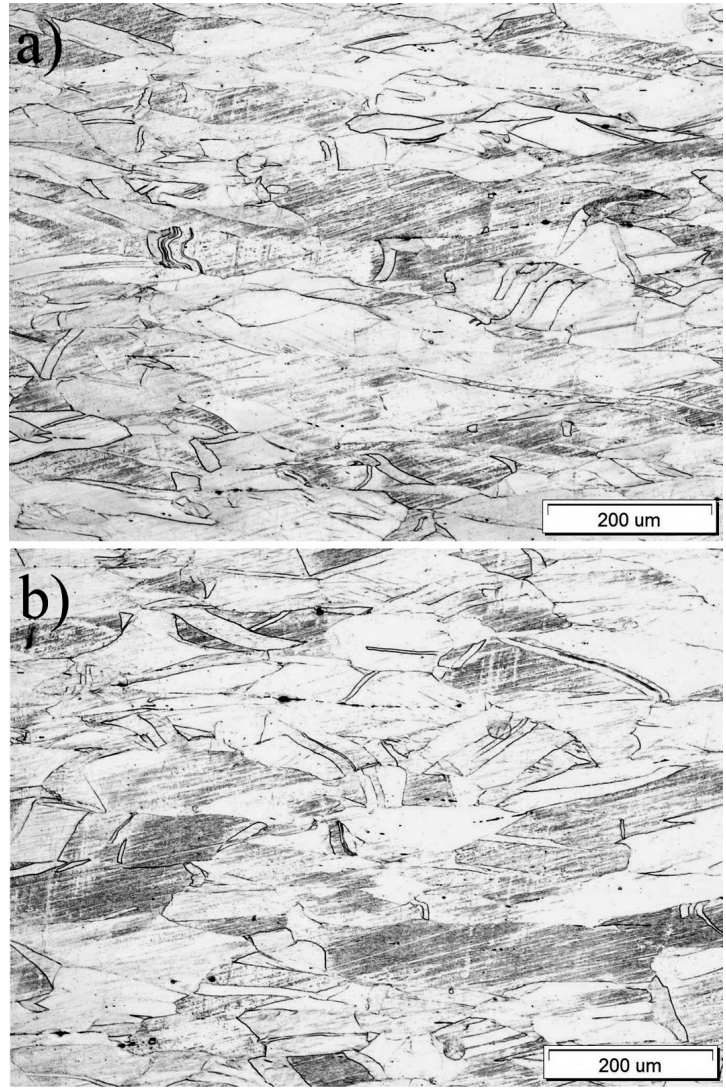

Figure 1: Austenitic microstructure of the thermomechanically processed: a) $27 \mathrm{Mn}-4 \mathrm{Si}-2 \mathrm{Al}$ and b) $26 \mathrm{Mn}-3 \mathrm{Si}-3 \mathrm{Al}$ steels

Slika 1: Avstenitna mikrostruktura termomehansko izdelanih jekel: a) $27 \mathrm{Mn}-4 \mathrm{Si}-2 \mathrm{Al}$ in b) $26 \mathrm{Mn}-3 \mathrm{Si}-3 \mathrm{Al}$
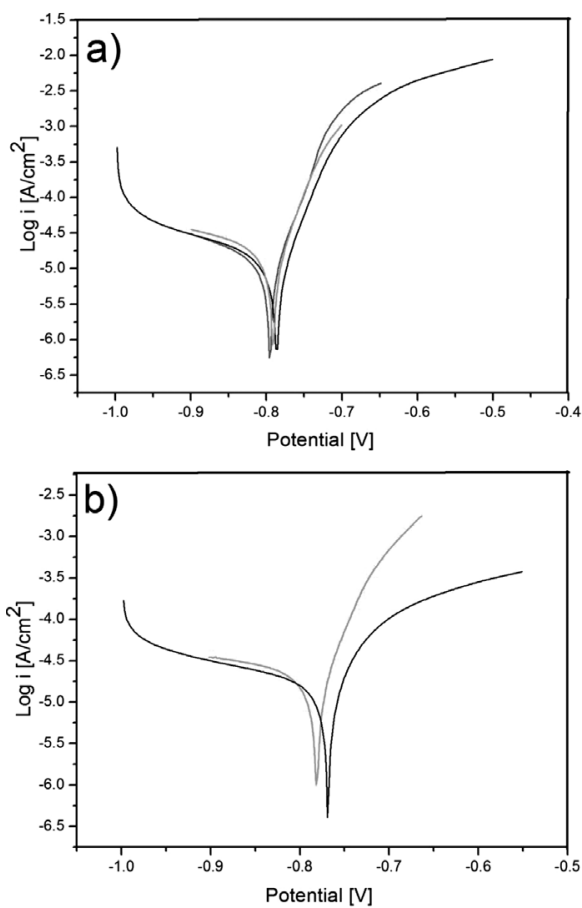

Figure 2: Potentiodynamic polarization curves of the: a) $27 \mathrm{Mn}$ $4 \mathrm{Si}-2 \mathrm{Al}$ and b) $26 \mathrm{Mn}-3 \mathrm{Si}-3 \mathrm{Al}$ steels obtained in $3.5 \% \mathrm{NaCl}$ solution Slika 2: Krivulje potenciodinamične polarizacije jekel v raztopini $3,5 \% \mathrm{NaCl}:$ a) $27 \mathrm{Mn}-4 \mathrm{Si}-2 \mathrm{Al}$ in b) $26 \mathrm{Mn}-3 \mathrm{Si}-3 \mathrm{Al}$ corrosion resistance in the chloride medium than in the alkaline solution.

In the $3.5 \% \mathrm{NaCl}$ solution, the $27 \mathrm{Mn}-4 \mathrm{Si}-2 \mathrm{Al}$ steel specimens showed a much higher corrosion current density $\left(0.09 \mathrm{~mA} / \mathrm{cm}^{2}\right)$ than the $26 \mathrm{Mn}-3 \mathrm{Si}-3 \mathrm{Al}$ steel $\left(0.009 \mathrm{~mA} / \mathrm{cm}^{2}\right)$. This confirms our earlier results from the potentiodynamic polarisation tests. ${ }^{3}$ It is related to the higher $\mathrm{Al}$ and lower $\mathrm{Si}$ contents in $26 \mathrm{Mn}-3 \mathrm{Si}-3 \mathrm{Al}$ steel in comparison to the steel containing $2 \% \mathrm{Al}$ (Table 1). It is reported ${ }^{18}$ that a silicon addition decreases the corrosion resistance of steel. On the other hand, aluminium improves the corrosion resistance due to its tendency to form a protective $\mathrm{Al}_{2} \mathrm{O}_{3}$ passive layer on the steel surface in solutions of $\mathrm{pH} \sim 7$ (Pourbaix diagrams). ${ }^{19}$ All the specimens polarized in the $3.5 \% \mathrm{NaCl}$ solution show $E_{\text {corr }}$ values shifted to less noble potentials (Table 2) when compared to the specimens polarized in the $0.1-\mathrm{M}$ $\mathrm{NaOH}$ solution. The $E_{\text {corr }}$ shift was about $400 \mathrm{mV}$ towards the cathodic direction. The values of the corrosion-current density obtained in the $0.1-\mathrm{M} \mathrm{NaOH}$ were quite similar for both steels. The $27 \mathrm{Mn}-4 \mathrm{Si}-2 \mathrm{Al}$ steel specimens showed a corrosion current density of approximately $0.007 \mathrm{~mA} / \mathrm{cm}^{2}$, whereas it was 0.005 $\mathrm{mA} / \mathrm{cm}^{2}$ for the second steel. The better corrosion resistance of both steels in $0.1-\mathrm{M} \mathrm{NaOH}$ is related to the fact that in alkaline solutions, manganese precipitates as $\mathrm{Mn}(\mathrm{OH})_{2}$, which is slightly soluble in solutions with $\mathrm{pH}>13$, whereas in solutions of $\mathrm{pH} \sim 7$ the manganese dissolves as $\mathrm{Mn}^{2+}$ (Pourbaix diagrams). ${ }^{19}$

The morphology of the corrosion pits after the electrochemical tests were studied using the SEM and
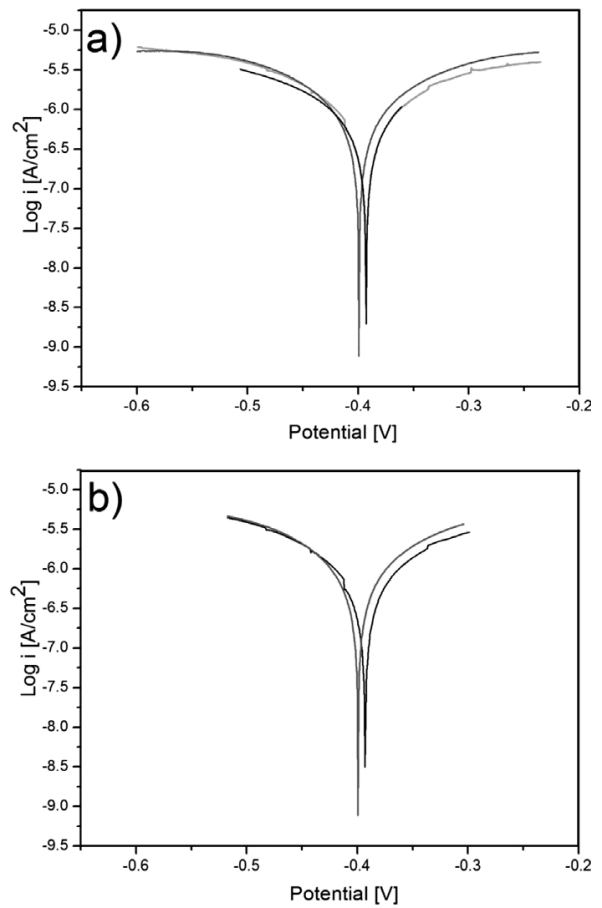

Figure 3: Potentiodynamic polarization curves of the: a) $27 \mathrm{Mn}-4 \mathrm{Si}$ $2 \mathrm{Al}$ and b) $26 \mathrm{Mn}-3 \mathrm{Si}-3 \mathrm{Al}$ steels obtained in $0.1-\mathrm{M} \mathrm{NaOH}$ solution

Slika 3: Krivulje potenciodinamične polarizacije jekel v raztopini $0,1 \mathrm{M} \mathrm{NaOH}$ : a) $27 \mathrm{Mn}-4 \mathrm{Si}-2 \mathrm{Al}$ in b) $26 \mathrm{Mn}-3 \mathrm{Si}-3 \mathrm{Al}$ 

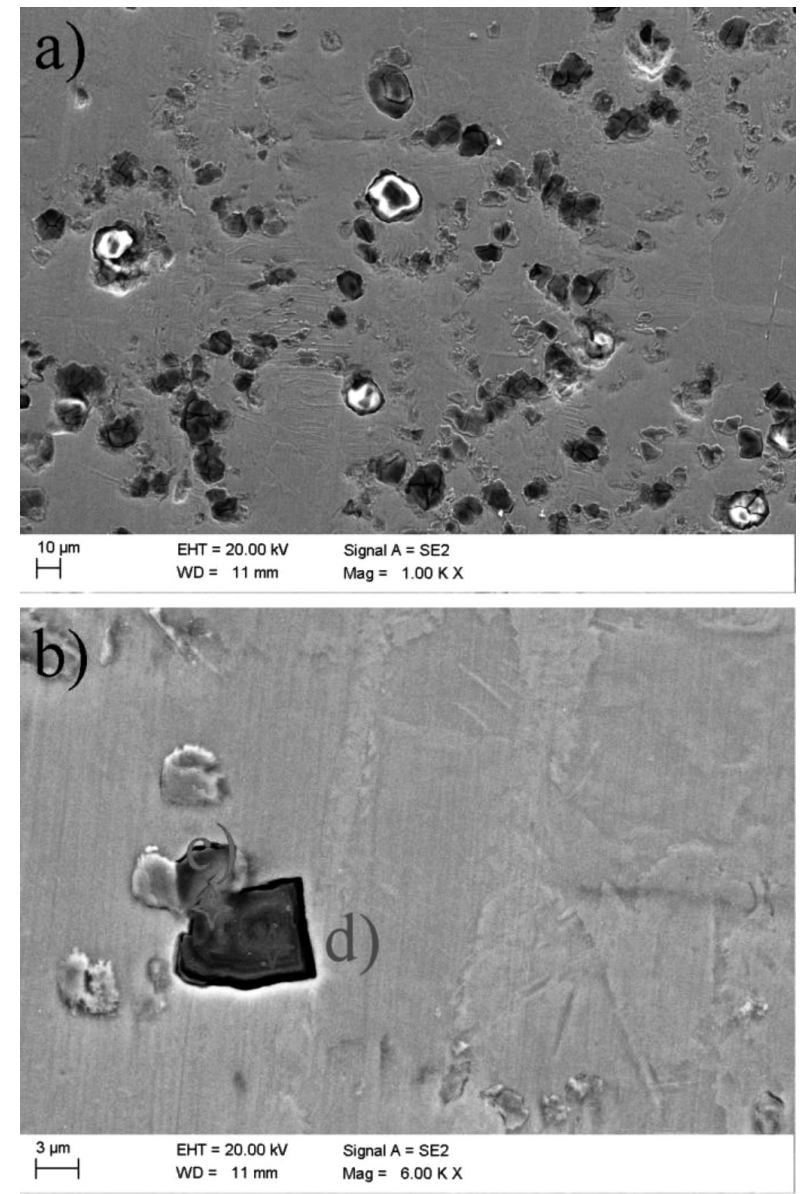

c)
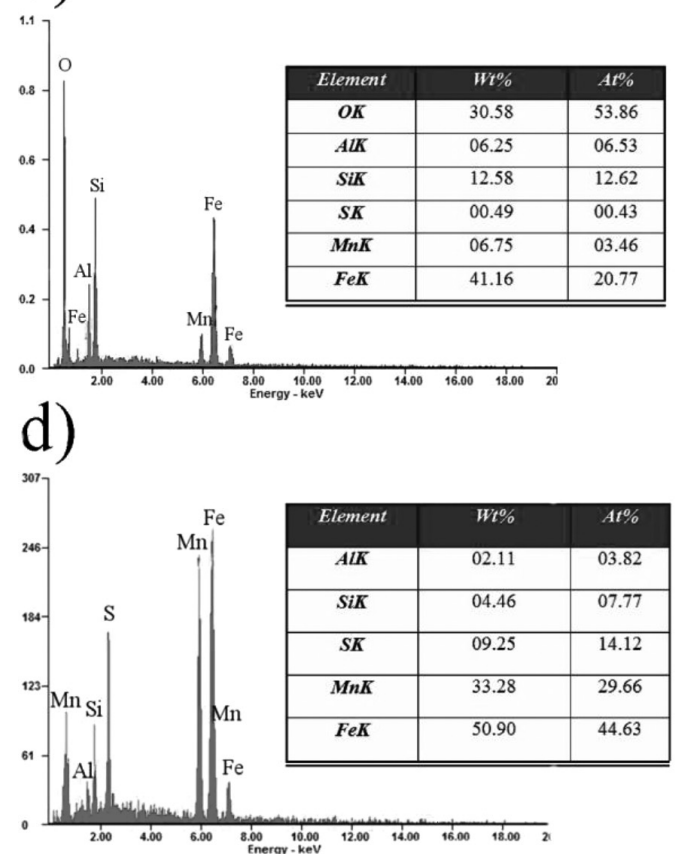

Figure 4: a) SEM micrograph of the $27 \mathrm{Mn}-4 \mathrm{Si}-2 \mathrm{Al}$ steel surface, b) the individual pit interior, c) EDS analysis from point D, d) EDS analysis from point $\mathrm{C}$ after corrosion test in $3.5 \% \mathrm{NaCl}$

Slika 4: a) SEM-posnetki površine jekla 27Mn-4Si-2Al, b) izgled posamezne jamice, c) EDS-analiza v točki D, d) EDS-analiza točke C po korozijskem preizkusu v $3,5 \% \mathrm{NaCl}$
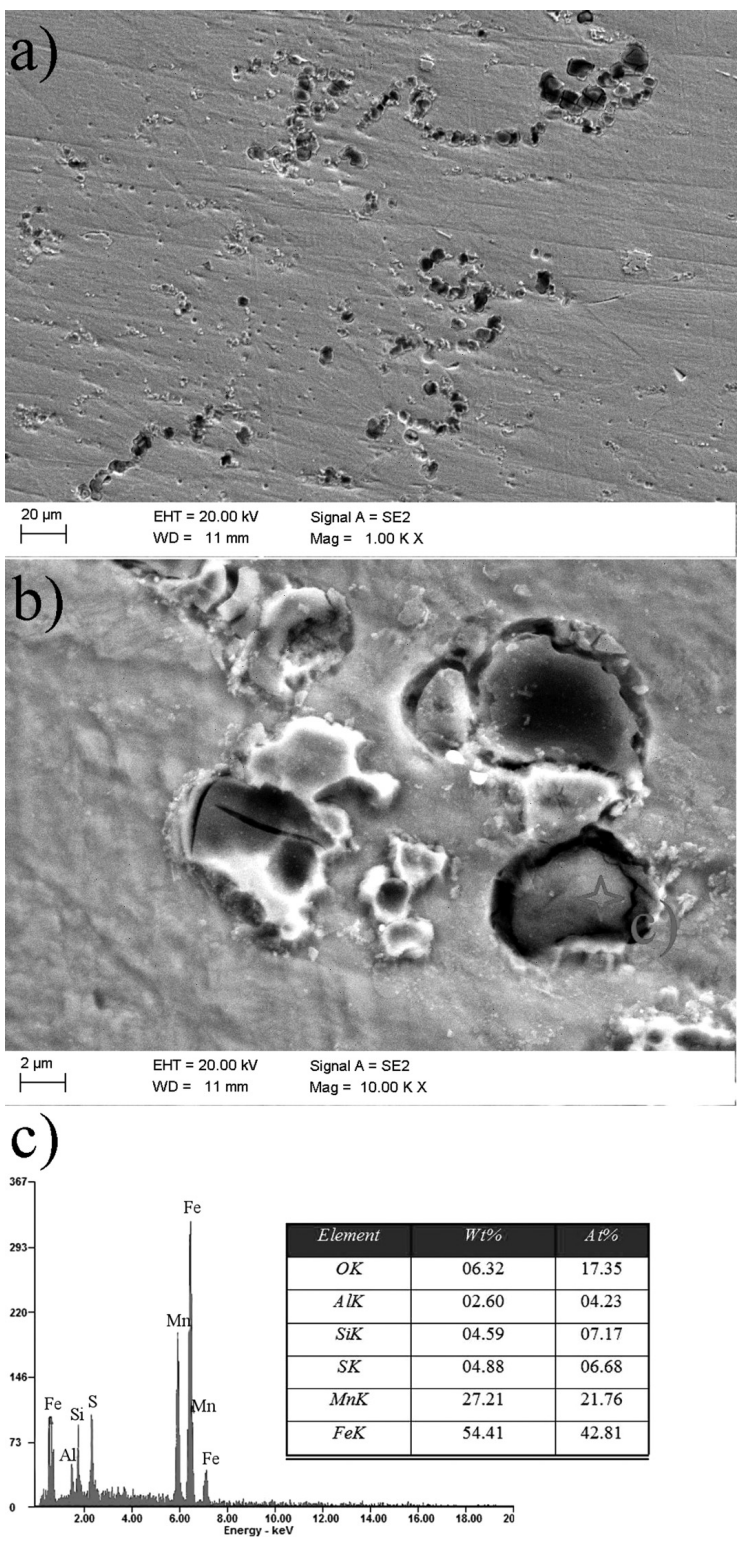

Figure 5: a) SEM micrograph of the $26 \mathrm{Mn}-3 \mathrm{Si}-3 \mathrm{Al}$ steel surface, b) the individual pit interior, c) EDS analysis from point $\mathrm{C}$ after corrosion test in $3.5 \% \mathrm{NaCl}$

Slika 5: a) SEM-posnetek površine jekla $26 \mathrm{Mn}-3 \mathrm{Si}-3 \mathrm{Al}$, b) izgled posamezne jamice, c) EDS-analiza točke $\mathrm{C}$ po korozijskem preizkusu v $3,5 \% \mathrm{NaCl}$

EDS techniques. The SEM images of the corrosion damage in both steels after the corrosion tests in $3.5 \%$ $\mathrm{NaCl}$ are shown in Figures 4 and 5. The corrosion pits are characterized by various shapes and an irregular distribution at the metallic matrix (Figures 4a and 5a). They are formed both at the grain boundaries and within the austenite grains. It is apparent that the pits are initiated at non-metallic inclusions. The EDS analysis revealed the variation of the chemical composition in the interior of the individual pits. For instance, the chemical composition of the particle inside the corrosion pit in Figure $4 \mathbf{b}$ showed a high content of manganese and sulphur (Figure 4d). This indicates that the privileged 

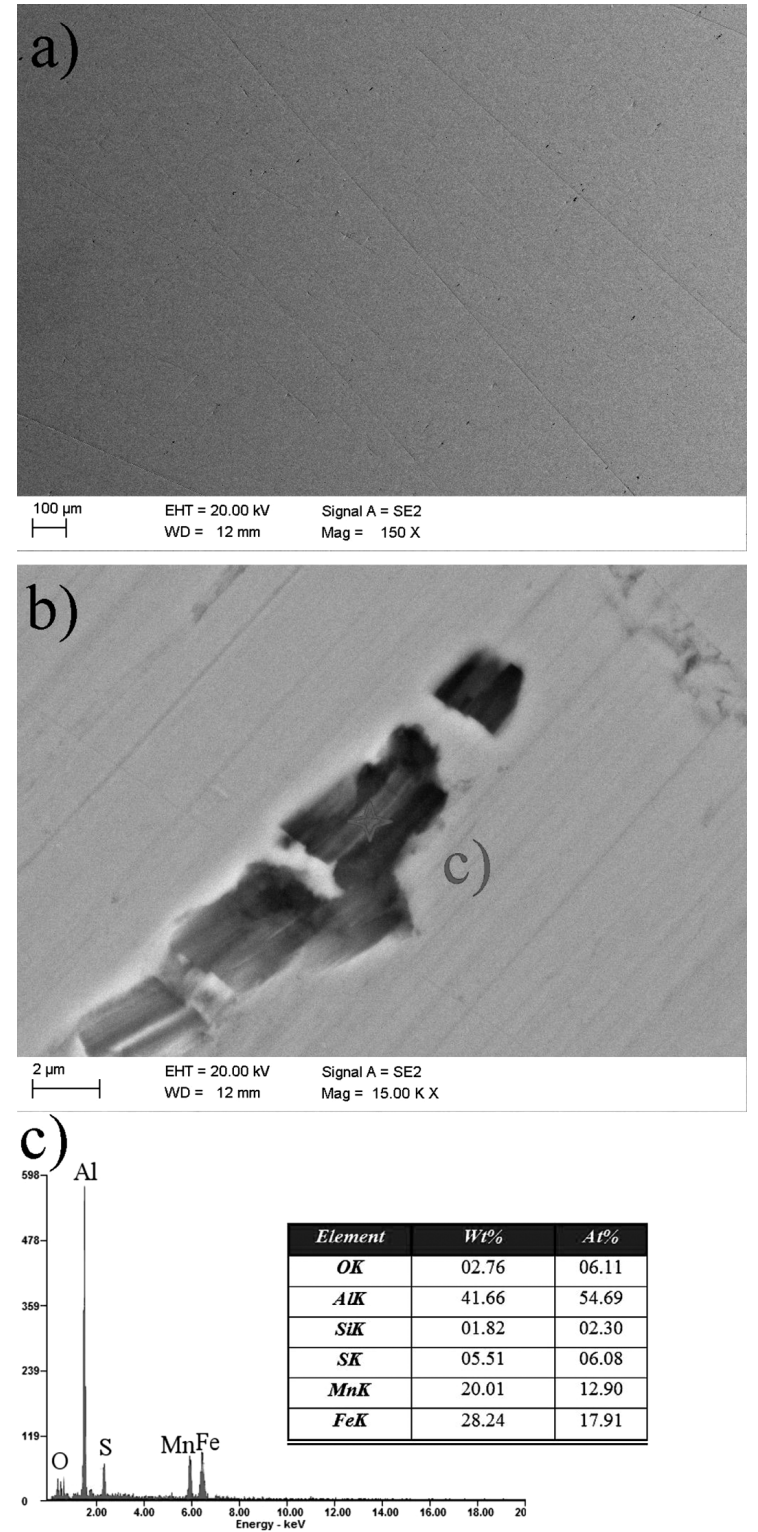

Figure 6: a) SEM micrograph of the $27 \mathrm{Mn}-4 \mathrm{Si}-2 \mathrm{Al}$ steel surface, b) the individual pit interior, c) EDS analysis from point $\mathrm{C}$ after corrosion test in $0.1-\mathrm{M} \mathrm{NaOH}$

Slika 6: a) SEM-posnetek površine jekla $27 \mathrm{Mn}-4 \mathrm{Si}-2 \mathrm{Al}$, b) izgled posamezne jamice, c) EDS-analiza iz točke $\mathrm{C}$ po korozijskem preizkusu v $0,1 \mathrm{M} \mathrm{NaOH}$

places for the pit initiation are MnS inclusions. There are many reports in the literature ${ }^{5-7,20}$ that confirm that $\mathrm{MnS}$ inclusions are vulnerable for the initiation of corrosion pits. Their presence increases the corrosion current density and displaces the $E_{\text {corr }}$ values towards less noble potentials. The chemical analysis of the corrosion damage shown in Figure $\mathbf{4 b}$ also revealed the presence of oxides containing $\mathrm{Al}$ and $\mathrm{Si}$ (Figure 4c).

Similar results were obtained for corrosion pits created in the steel containing the higher Al content (26Mn-3Si-3Al steel). The pits are preferentially initiated along the grain boundaries (Figure 5a). The EDS analysis showed the presence of corrosion pits at parti-
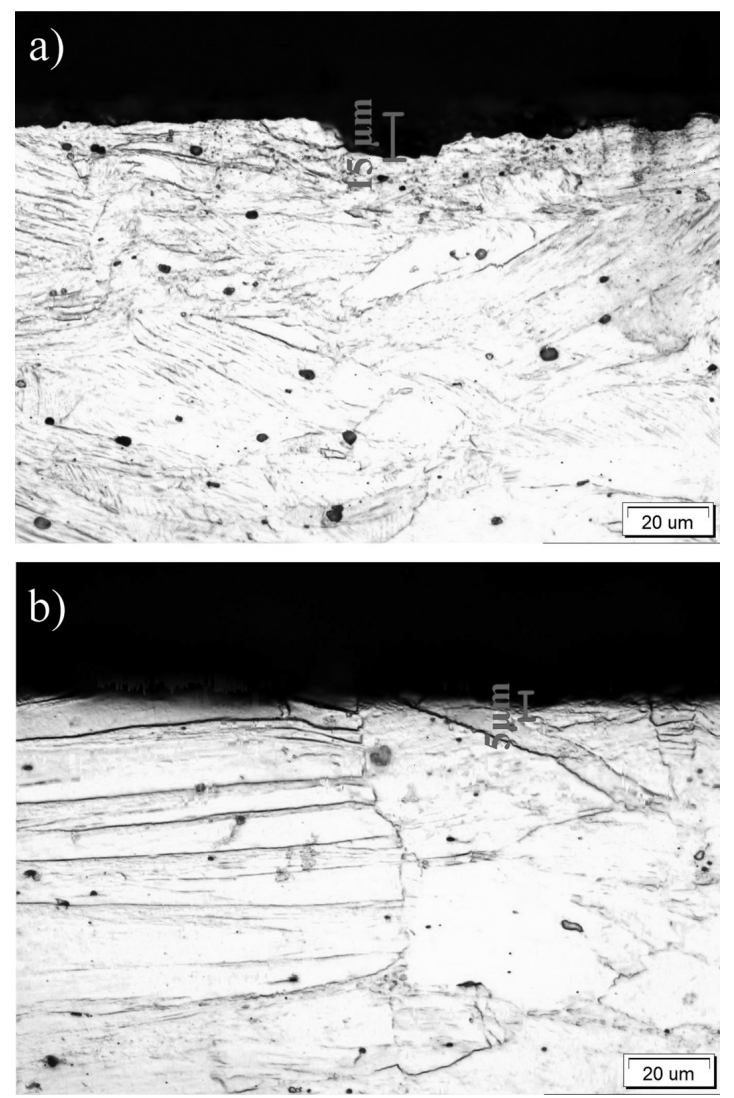

Figure 7: Light micrographs of the cross-section of $27 \mathrm{Mn}-4 \mathrm{Si}-2 \mathrm{Al}$ steel potentiodynamically polarized in: a) chloride solution and b) alkaline solution

Slika 7: Posnetek preseka jekla 27Mn-4Si-2Al potenciodinamično polariziranega v: a) kloridni raztopini in b) alkalni raztopini

cles with the high concentrations of manganese and sulphur, too (Figures $\mathbf{5 b}$ and $\mathbf{5 c}$ ). The resistance to pitting corrosion strongly depends on the quantity, size and type of non-metallic inclusions in the metallic matrix. ${ }^{11}$ Park et al. ${ }^{7}$ found that the size of the $\mathrm{MnS}$ inclusions increased with an increase in the Mn content from 6 to $12 \%$ in the high-Cr steel. This is why both high-Mn steels contain a lot of corrosion damage.

The SEM images of both high-Mn steels after the corrosion tests in $0.1-\mathrm{M} \mathrm{NaOH}$ show good agreement with the results of the potentiodynamic tests. The observation of the steel surfaces (Figure 6a) confirmed a substantial reduction in the amount of corrosion damage. The EDS analyses of the individual pit in Figures $\mathbf{6 b}$ and 6c revealed a high content of $\mathrm{Mn}, \mathrm{S}, \mathrm{Al}, \mathrm{Si}$ and $\mathrm{O}$, which indicates that complex oxysulphides containing $\mathrm{Mn}, \mathrm{Al}$ and $\mathrm{Si}$ are also preferential sites for pit formation in the alkaline solution. According to I. J. Park et al. ${ }^{21} \mathrm{Al}_{2} \mathrm{O}_{3}$ particles have a higher resistance to pit formation than MnS particles.

The nature of the corrosion damage was evaluated on cross-sectioned specimens. In the chloride solution, the specimens showed evidence of uniform corrosion. In addition to uniform corrosion, pitting corrosion was also 
observed (Figure 7). Other authors ${ }^{5-7,16}$ observed corrosion pits in different high-manganese steels after polarization tests in chloride solution too. After the corrosion tests in $3.5 \% \mathrm{NaCl}$ the maximum depth of the corrosion pits in the steel containing $2 \% \mathrm{Al}$ was evaluated to be $15 \mu \mathrm{m}$ (Figure 7a). Similar corrosion pits were also identified for the $26 \mathrm{Mn}-3 \mathrm{Si}-3 \mathrm{Al}$ steel. The corrosion damage formed in both steels in the alkaline medium is characterized by a small depth of $5 \mu \mathrm{m}$ (Figure $7 \mathbf{b}$ ). However, the quantity of corrosion damage was much lower when compared to the samples investigated in the chloride medium.

\section{CONCLUSIONS}

The morphology of corrosion damage after electrochemical tests in $3.5 \% \mathrm{NaCl}$ and $0.1-\mathrm{M} \mathrm{NaOH}$ supports the data registered in potentiodynamic tests. The high-Mn steels are characterized by a low corrosion resistance, especially in a chloride solution, where corrosion damage is more numerous. The corrosion pits are characterized by various shapes and are distributed irregularly both at grain boundaries and within the grains. EDS analyses confirmed that the corrosion pits nucleated preferentially on the $\mathrm{MnS}$ inclusions and complex oxysulphides containing $\mathrm{Mn}, \mathrm{Al}$ and $\mathrm{Si}$. The low density of corrosion damage in the alkaline solution is related to the fact that $\mathrm{Mn}$ precipitates as $\mathrm{Mn}(\mathrm{OH})_{2}$, which is slightly soluble in solutions of $\mathrm{pH}>13$, whereas in solutions of $\mathrm{pH} \sim 7$ the manganese dissolves as $\mathrm{Mn}^{2+}$. The concentration of the individual alloying elements was not strongly related to the corrosion behaviour of the steels in $0.1-\mathrm{M} \mathrm{NaOH}$, in contrast to the $3.5 \% \mathrm{NaCl}$ solution. The increased contents of $\mathrm{Mn}$ and $\mathrm{Si}$ and the smaller content of $\mathrm{Al}$ are reflected in the lower corrosion resistance of the $27 \mathrm{Mn}-4 \mathrm{Si}-2 \mathrm{Al}$, as registered during the potentiodynamic tests.

\section{Acknowledgment}

This work was financially supported with statutory funds of the Faculty of Mechanical Engineering of the Silesian University of Technology in 2015.

\section{REFERENCES}

${ }^{1}$ P. C. Pistorius, G. T. Burstein, Metastable pitting corrosion of stainless steel and the transition to stability, Philosophical Transactions of the Royal Society A, 341 (1992), 531-559

${ }^{2}$ A. Grajcar, A. Płachcińska, S. Topolska, M. Kciuk, Effect of thermomechanical treatment on the corrosion behaviour of Si- and Al-containing high-Mn austenitic steel with $\mathrm{Nb}$ and $\mathrm{Ti}$ micro-additions, Mater. Tehnol., 49 (2015) 6, 889-894, doi:10.17222/mit.2014.148

${ }^{3}$ A. Grajcar, A. Płachcińska, M. Kciuk, S. Topolska, Microstructure and corrosion behavior of hot-deformed and cold-strained high-Mn steels, Journal of Materials Engineering and Performance, 26 (2016) 6, 2245-2254, doi: 10.1007/s11665-016-2085-5
${ }^{4}$ S. Lasek, E. Mazancova, Influence of thermal treatment on structure and corrosion properties of high manganese triplex steels, Metalurgija, 52 (2013) 4, 441-444

${ }^{5}$ C. Donik, I. Paulin, M. Jenko, Influence of MnS inclusions on the corrosion of austenitic stainless steels, Mater. Tehnol., 44 (2010) 2 , 67-72

${ }^{6}$ A. Pardo, M. C. Merno, A. E. Coy, F. Viejo, R. Arrabal, E. Matykina, Pitting corrosion behaviour of austenitic stainless steels - combining effects of Mn and Mo additions, Corrosion Science, 50 (2008), 1796-1806, doi:10.1016/j.corsci.2008.04.005

${ }^{7}$ I. J. Park, S. M. Lee, M. Kang, S. Lee, Y. K. Lee, Pitting corrosion behavior in advanced high strength steels, Journal of Alloys and Compounds, 619 (2015), 205-210, doi:10.1016/j.jallcom.2014. 08.243

${ }^{8}$ A. Grajcar, M. Opiela, G. Fojt-Dymara, The influence of hot-working conditions on a structure of high-manganese steel, Archives of Civil and Mechanical Engineering, 9 (2009) 3, 49-58

${ }^{9}$ M. Jablońska, A. Śmiglewicz, Analysis of substructure of high-Mn steels in the context of dominant stress mechanism, Defect and Diffusion Forum, 334-335 (2013), 177-181, doi:10.4028/DDF. 334-335.177

${ }^{10}$ L. A. Dobrzański, A. Grajcar, W. Borek, Microstructure evolution of $\mathrm{C}-\mathrm{Mn}$-Si-Al-Nb high-manganese steel during the thermomechanical processing, Materials Science Forum, 638-642 (2010), 3224-3229, doi:10.4028/MSF.638-642.3224

${ }^{11}$ A. Grajcar, U. Galisz, L. Bulkowski, Non-metallic inclusions in. high manganese austenitic alloys, Archives of Materials Science and Engineering, 50 (2011), 21-30

${ }^{12}$ A. Grajcar, M. Różański, M. Kamińska, B. Grzegorczyk, Study on non-metallic inclusions in laser-welded TRIP-aided $\mathrm{Nb}$ microalloyed steel, Archives of Metallurgy and Materials, 59 (2014) 3, 1163-1169, doi:10.2478/amm-2014-0203

${ }^{13}$ K. J. Park, H. S. Kwon, Effects of Mn on the localized corrosion behavior of $\mathrm{Fe}-18 \mathrm{Cr}$ alloys, Electrochimica Acta, 55 (2010), 3421-3427, doi:10.1016/j.electacta.2010.01.006

${ }^{14}$ M. Jabłońska, G. Niewielski, R. Kawalla, High manganese TWIP steel - technological plasticity and selected properties, Solid State Phenomena, 212 (2014), 87-90, doi:10.4028/SSP.212.87

${ }^{15}$ A. Grajcar, R. Kuziak, Softening kinetics in Nb-microalloyed TRIP steels with increased Mn content, Advanced Materials Research, 314-316 (2011), 119-122, doi:10.4028/AMR.314-316.119

${ }^{16}$ M. B. Kannan, R. K. S. Raman, S. Khoddam, Comparative studies on the corrosion properties of a $\mathrm{Fe}-\mathrm{Mn}-\mathrm{Al}-\mathrm{Si}$ steel and an interstitial-free steel, Corrosion Science, 50 (2008), 2879-2884, doi:10.1016/j.corsci.2008.07.024

${ }^{17}$ Y. S. Zhang, X. M. Zhu, S. H. Zhong, Effect of alloying elements on the electrochemical polarization behavior and passive film of $\mathrm{Fe}-\mathrm{Mn}$ base alloys in various aqueous solutions, Corrosion Science, 46 (2004), 853-876, doi:10.1016/j.corsci.2003.09.002

${ }^{18}$ S. Suzuki, E. Matsubara, T. Komatsu, Y. Okamoto, K. Kanie, A. Muramatsu, H. Konishi, J. Mizuki, Y. Waseda, Ex-situ and in-situ $\mathrm{X}$-ray diffractions of corrosion products freshly formed on the surface of an iron-silicon alloy, Corrosion Science, 49 (2007), 1081-1096, doi:10.1016/j.corsci.2006.06.029

${ }^{19}$ N. Takeno, Atlas of Eh-pH diagrams, National Institute of Advanced Science and Technology, Tokyo 2005

${ }^{20}$ A. Abbasi Aghuy, M. Zakeri, M. H. Moayed, M. Mazinani, Effect of grain size on pitting corrosion of $304 \mathrm{~L}$ austenitic stainless steel, Corrosion Science, 94 (2015), 368-376, doi:10.1016/j.corsci. 2015.02.024

${ }^{21}$ I. J. Park, S. T. Kim, I. S. Lee, Y. S. Park, M. B. Moon, A study on corrosion behavior of DP-type and TRIP-type cold rolled steel sheet, Materials Transactions (JIM), 50 (2009), 1440-1447 